\title{
AKSES MASYARAKAT DALAM PEMANFAATAN SUMBER DAYA AIR
}

\author{
Community Access in Water Resources Utilization
}

\author{
Amelia Ari Putri ${ }^{1)}$, dan Martua Sihaloho ${ }^{1)}$ \\ ${ }^{1)}$ Departemen Sains Komunikasi dan Pengembangan Masyarakat, Fakultas Ekologi Manusia, \\ Institut Pertanian Bogor, Darmaga Bogor 16680, Indonesia \\ E-mail: ameliaariputri@gmail.com; martuashlh@apps.ipb.ac.id
}

\begin{abstract}
The existence of Constitution Number 7 Year 2004 on Water Resources become the foundation of open opportunity for water commercialization and commodification. The private sector has opportunity in water concessions through the granting of entitlements that lead to changes in resource ownership regimes. The establishment of water company makes the abundance of water resources that can be utilized by the community to fulfil their socio-economic needs being reduced. Villagers often mean that the presence of private sector will reduce water utilization in their area, thus feeling their access to water use will be limited. This study aims to analyze the influence of community access in utilizing water resources to socio-economic conditions of society. This research is located in Sukamantri Village, Tamansari District, Bogor Regency, West Java. The method used to extract facts, data, and information in the research is quantitative approach through survey method with questionnaires, and supported by qualitative data through interview and literature study until obtained by analysis result that access of water resources utilization by society influence their socioeconomic.
\end{abstract}

Keywords: Access, regime property, socio-economic, water resources

\begin{abstract}
ABSTRAK
Adanya UU Nomor 7 Tahun 2004 tentang Sumber Daya Air menjadikan landasan terbukanya kesempatan bagi upaya komersialisasi dan komodifikasi air. Sektor swasta berkesempatan dalam pengusahaan air lewat pemberian hak guna usaha yang menyebabkan terjadinya perubahan rezim kepemilikan sumber daya. Berdirinya Perusahaan air membuat kelimpahan sumber daya air yang dapat dimanfaatkan oleh masyarakat untuk memenuhi kebutuhan sosial ekonominya menjadi berkurang. Masyarakat desa sering memaknai bahwa kehadiran pihak swasta akan mengurangi pemanfaatan air di wilayah mereka, sehingga merasa akses mereka dalam pemanfaatan air akan terbatasi. Penelitian ini bertujuan untuk menganalisis pengaruh akses masyarakat dalam memanfaatkan sumber daya air terhadap kondisi sosial ekonomi masyarakat. Penelitian ini berlokasi di Desa Sukamantri, Kecamatan Tamansari, Kabupaten Bogor, Jawa Barat. Metode yang digunakan untuk menggali fakta, data, dan informasi dalam penelitian adalah pendekatan kuantitatif melalui metode survei dengan kuesioner, dan didukung oleh data kualtitatif melalui wawancara dan studi literatur hingga diperoleh hasil analisis bahwa akses pemanfaatan sumber daya air oleh masyarakat mempengaruhi kondisi sosial ekonomi masyarakat.
\end{abstract}

Kata kunci: Akses, rezim kepemilikan, sumber daya air, sosial ekonomi

\section{PENDAHULUAN}

Sumber daya air merupakan bagian dalam sistem ekologi. Sebagai suatu sistem ekologi, sumber daya air memiliki hubungan timbal balik yang erat dengan sistem sosial dan berbagai aktivitas masyarakat sehari-hari dalam rangka memenuhi kebutuhan sosial dan ekonomi. Menurut Undangundang Nomor 7 Tahun 2004 tentang Sumber Daya Air pasal 5 disebutkan bahwa "Negara menjamin hak setiap orang untuk mendapatkan air bagi kebutuhan pokok minimal sehari-hari guna memenuhi kehidupannya yang sehat, bersih, dan produktif". Secara eksplisit isi ayat tersebut menunjukkan bahwa untuk dapat memperoleh air bersih adalah hak setiap orang, warganegara dari suatu negara.

Sumber daya air memiliki karakteristik sebagai sumber daya bersama (common pool resources) yang memiliki tantangan tersendiri. Keberadaan common pool resources yang bersifat open to all, 
menyisakan konsekuensi yaitu kebebasan bagi pengguna untuk mengakses sumber daya bersama sehingga para pengguna tidak dapat melarang pengguna lainnya namun timbul persaingan di antara para pengguna tersebut (Wade 1987). Berdasarkan Undang-undang Nomor 7 Tahun 2004 Pasal 77 ayat (3) huruf c, menyatakan bahwa salah satu sumber dana pembiayaan sumber daya air dapat diperoleh dari hasil penerimaan biaya jasa pengelolaan sumber daya air. Adanya UU tersebut menjadi landasan terbukanya kesempatan bagi upaya komersialisasi dan komodifikasi air.

Perubahan makna air dari barang publik menjadi barang ekonomi yang dikuasai oleh perusahaanperusahaan swasta untuk menghindari terjadinya tragedy of the commons (Hardin 1968) yaitu terjadinya kerusakan sumber daya karena keinginan semua pihak untuk memanfaatkan dan mengeksploitasi sumber daya alam tersebut, maka dari itu status kepemilikan akses terbuka (open acces property) perlu dialihkan menjadi kepemilikan swasta (privat property). Privatisasi dalam pengelolaan sumber daya air merupakan solusi dari kegagalan publik mengelola sumber daya air secara efektif dan efisien. Penyerahan penguasaan pengelolaan sumber daya air kepada swasta juga menutup akses masyarakat terhadap sumber daya air tersebut. Perusahaan-perusahaan mendapatkan keuntungan dari naiknya permintaan terhadap air sementara masyarakat kehilangan haknya atas air dan kehilangan mata pencaharian (Shiva 2002).

Air pegunungan merupakan asset produktif yang dapat diolah untuk menghasilkan pendapatan yang seringkali dimanfaatkan oleh pihak swasta sebagai usaha pemanfaatan jasa lingkungan bidang industri seperti pembangunan Perusahaan Air Minum Dalam Kemasan (AMDK). Berdirinya Perusahaan AMDK ditengah kehidupan masyarakat desa tidak jarang menimbulkan permasalahan tekait sumber daya air seperti terjadinya kelangkaan air. Bagi pandangan ekonomi, kelangkaan menjadi akspek penting bagi bekerjanya ekonomi. Ketersediaan air yang terbatas mengakibatkan berlakunya hukum ekonomi bahwa air merupakan benda yang dapat diperjualbelikan.

Kecamatan Tamansari merupakan salah satu kecamatan di Kabupaten Bogor yang berbatasan dengan Gunung Salak. Desa Sukamantri merupakan desa yang bertipologi pada bidang jasa. Desa Sukamantri menjadi salah satu tempat berdirinya
Perusahaan AMDK. Berdirinya Perusahaan AMDK di tengah pemukiman masyarakat pedesaan tentunya berkaitan pada kondisi sumber daya air. Kondisi sumber daya air yang mengalami perubahan ini secara langsung maupun tidak langsung mempengaruhi akses dan perubahan kehidupan masyarakat yang menggantungkan kehidupannya dari memanfaatkan potensi sumber daya air. Tulisan ini berfokus pada akses sumber daya air dari perspektif akses masyarakat dengan pihak swasta. Aspek kehidupan dan penghidupan masyarakat difokuskan pada akses masyarakat terhadap pemanfaatan sumber daya air setelah berdirinya Perusahaan AMDK bagi kehidupan sosial ekonomi masyarakat yang bisa menjelaskan interaksi antara sumber daya air dengan masyarakat.

Berdasarkan hal tersebut, maka tulisan ini memiliki pertanyaan: (1) bagaimana akses pemanfaatan sumber daya air oleh masyarakat?; (2) bagaimana kondisi sosial ekonomi masyarakat setelah masuknya Perusahaan AMDK?; dan (3) bagaimana pengaruh akses pemanfaatan sumber daya air terhadap kondisi sosial ekonomi masyarakat? Sementara pada tulisan ini memiliki tujuan: (1) menganalisis akses pemanfaatan sumber daya air oleh masyarakat; (2) menganalisis kondisi sosial ekonomi masyarakat; dan (3) menganalisis pengaruh akses pemanfaatan sumber daya air terhadap kondisi sosial ekonomi masyarakat.

\section{PENDEKATAN TEORITIS}

\section{Konsep Sumber Daya Air}

Berdasarkan Undang-undang Nomor 7 Tahun 2004 tentang Sumber Daya Air, yang dimaksud dengan air adalah semua air yang terdapat pada, di atas, maupun di bawah permukaan tanah, termasuk dalam pengertian ini air permukaan, air tanah, air hujan, dan air laut yang berada di darat. Sumber daya air mempunyai fungsi sosial, lingkungan hidup, dan ekonomi yang diselenggarakan dan diwujudkan secara selaras. Semua orang memiliki hak untuk memanfaatkan sumber daya air. Hak yang dimaksud yaitu hak guna air, hak guna pakai air, dan hak guna usaha air. Hak guna air adalah hak untuk memperoleh dan memakai atau mengusahakan air untuk berbagai keperluan. Hak guna pakai air adalah hak untuk memperoleh dan memakai air. Hak guna usaha air adalah hak untuk memperoleh dan mengusahakan air (UU No. 7 Tahun 2004). 
Sumber daya air yang ada di bumi merupakan barang yang bersifat sumber daya bersama. Setiap orang mempunyai hak yang sama dalam memanfaatkan sumber daya air untuk memenuhi kebutuhan dasar hidup masing-masing. Menurut Kodoatie dan Sjarie (2008) kebutuhan air manusia meliputi air bersih domestik dan non domestik. Kebutuhan air domestik merupakan air yang digunakan untuk keperluan rumahtangga. Sedangkan kebutuhan air non domestik merupakan air yang digunakan untuk industri, pariwisata, tempat ibadah, tempat sosial, serta tempat-tempat komersial atau tempat umum lainnya.

\section{Tipe Barang Sumber Daya}

Ostrom (2005) seperti yang dikutip Rustiadi et al. (2011) menjelaskan bahwa ada empat klasifikasi barang (goods) ekonomi menurut sifat pembagian cara memperoleh dan persaingannya yang penjelasannya disajikan pada Tabel 1 .

Tabel 1 Klasifikasi barang (Goods) ekonomi

\begin{tabular}{|c|c|c|c|}
\hline \multirow{2}{*}{\multicolumn{2}{|c|}{$\begin{array}{l}\text { Pembagian cara } \\
\text { klasik barang } \\
\text { ekonomi }\end{array}$}} & \multicolumn{2}{|c|}{$\begin{array}{c}\text { Mampu melarang atau } \\
\text { membatasi pihak luar untuk } \\
\text { mengakses } \\
\text { (Excludability)? }\end{array}$} \\
\hline & & $\begin{array}{c}\text { Ya } \\
\text { (Excludable) }\end{array}$ & $\begin{array}{c}\text { Tidak (Non } \\
\text { Excludable) }\end{array}$ \\
\hline \multirow{2}{*}{$\begin{array}{l}\text { Barang } \\
\text { diperoleh } \\
\text { dengan } \\
\text { bersaing }\end{array}$} & $\begin{array}{c}\mathrm{Ya} \\
\text { (Rivalry) }\end{array}$ & $\begin{array}{l}\text { Private goods } \\
\text { (pakaian, } \\
\text { pangan, } \\
\text { kendaraan, } \\
\text { elektronik) }\end{array}$ & $\begin{array}{c}\text { Common goods } \\
\text { (Common-pool } \\
\text { resources) } \\
\text { Sistem irigasi, } \\
\text { ikan laut, hutan }\end{array}$ \\
\hline & $\begin{array}{l}\text { Tidak } \\
\text { (Non } \\
\text { Rivarly) }\end{array}$ & $\begin{array}{l}\text { Club good } \\
\text { Klub golf, } \\
\text { TV kabel }\end{array}$ & $\begin{array}{l}\text { Public goods } \\
\text { Udara, TV, } \\
\text { Pertahann } \\
\text { Negara }\end{array}$ \\
\hline
\end{tabular}

Sumber: Ostrom (2005) dalam Rustiadi et al. (2011)

Pada penjelasan Tabel 1 dapat diketahui bahwa sumber daya air termasuk sumber daya bersama (common pool resources) yang dapat dimanfaatkan oleh siapapun, dan diperoleh secara bersaing. Sumber daya bersama merupakan sumber daya yang keberadaannya bebas, namun tidak dapat dieksklusifkan oleh salah satu pihak sehingga ada persaingan antara pengguna. Di beberapa daerah, air masih dianggap sebagai public goods sehingga timbul kecenderungan air disia-siakan ketika berlimpah dan dicari ketika terjadi kelangkaan. Sumber daya air memiliki hak kepemilikan yang lemah sehingga air mudah mengalami perubahan dalam kuantitas dan kualitas sebagai akibat dari ketidakjelasan hak-hak atas pengelolaan dan pemanfaatannya.

\section{Teori Hak Kepemilikan (Property Right Theory)}

Bromley (1991) memandang property (kepemilikan) sebagai aliran manfaat atau keuntungan, dan property rights (hak kepemilikan) merupakan klaim untuk mendapatkan manfaat atau keuntungan yang di dalamnya terdapat otoritas (kewenangan) untuk melindungi dari gangguan orang lain. Properti bukanlah sebuah objek (benda) tapi mencerminkan sebuah hubungan sosial antara pemegang properti (property holder) dengan sesuatu yang bernilai untuk mendapatkan keuntungan. Menurut Bromley, ada empat rezim kepemilikan yaitu akses terbuka (open access), negara (state property), swasta (private property), dan komunal (common property). Penjelasan keempat rezim tersebut disajikan dalam Tabel 2.

Tabel 2 Tipe rezim kepemilikan

\begin{tabular}{|c|c|}
\hline $\begin{array}{c}\text { Rezim } \\
\text { kepemilikan }\end{array}$ & Pengertian \\
\hline $\begin{array}{l}\text { Akses } \\
\text { terbuka } \\
(\text { open access) }\end{array}$ & $\begin{array}{l}\text { Tidak ada aturan yang mengikat. } \\
\text { Memicu terjadinya tragedy of the } \\
\text { common, kerusakan sumber daya, } \\
\text { dan konflik antar pelaku kesenjangan } \\
\text { ekonomi. }\end{array}$ \\
\hline $\begin{array}{l}\text { Rezim negara } \\
\text { (state } \\
\text { property) }\end{array}$ & $\begin{array}{l}\text { Kepemilikan berada di tingkat daerah } \\
\text { hingga pusat, membutuhkan biaya } \\
\text { tinggi, seringkali berbenturan dan } \\
\text { tidak sesuai dengan kondisi lapang. }\end{array}$ \\
\hline $\begin{array}{l}\text { Rezim swasta } \\
\text { (privat } \\
\text { property) }\end{array}$ & $\begin{array}{l}\text { Hak kepemilikan biasanya bersifat } \\
\text { temporal (dalam jangka waktu } \\
\text { tertentu) karena izin yang diberikan } \\
\text { pemerintah. }\end{array}$ \\
\hline $\begin{array}{l}\text { Rezim } \\
\text { komunal } \\
\text { (common } \\
\text { property) }\end{array}$ & $\begin{array}{l}\text { Kekuasaan bersifat turun-temurun } \\
\text { lokal dan spesifik, dapat bersifat } \\
\text { tertulis dan tidak tertulis, dibuat dari } \\
\text { pengetahuan lokal dan pelaksanaanya } \\
\text { lebih efektif. }\end{array}$ \\
\hline
\end{tabular}

Sumber: Bromley (1991)

Selain tipe kepemilikan Bromley, Satria (2009) juga mengungkapkan tipe-tipe kepemilikan versi Ostrom dan Schlager (1999) yang meliputi:

1. Hak akses (access right): hak untuk masuk ke wilayah sumber daya yang memiliki batas-batas yang jelas dan untuk menikmati manfaat nonekstraktif.

2. Hak pemanfaatan (withdrawal right): hak untuk memanfaatkan sumber daya atau hak untuk 
berproduksi.

3. Hak pengelolaan (management right): hak untuk menentukan aturan operasional pemanfaatan sumber daya.

4. Hak eksklusi (excluison right): hak untuk menentukan siapa yang boleh memiliki hak akses dan bagaimana akses tersebut dialihkan ke pihak lain.

5. Hak pengalihan (alienation right): hak untuk menjual atau menyewakan sebagian atau seluruh hak-hak secara kolektif.

Hak-hak tersebut akan menunjukan pihak yang mendapatkan akses atas sumber daya air. Pihak tersebut nantinya akan memiliki status kepemilikan atas sumber daya yang dapat terlihat pada Tabel 3 .

Tabel 3 Status kepemilikan sumber daya alam

\begin{tabular}{lrrrrr}
\hline \multicolumn{1}{c}{ Tipe hak } & Owner & $\begin{array}{c}\text { Propri } \\
\text { etor }\end{array}$ & $\begin{array}{c}\text { Claim } \\
\text { ant }\end{array}$ & $\begin{array}{c}\text { Author } \\
\text { ized } \\
\text { user }\end{array}$ & $\begin{array}{c}\text { Author } \\
\text { ized } \\
\text { entrant }\end{array}$ \\
\hline Akses & $\mathrm{X}$ & $\mathrm{X}$ & $\mathrm{X}$ & $\mathrm{X}$ & $\mathrm{X}$ \\
Pemanfaatan & $\mathrm{X}$ & $\mathrm{X}$ & $\mathrm{X}$ & $\mathrm{X}$ & \\
Pengelolaan & $\mathrm{X}$ & $\mathrm{X}$ & $\mathrm{X}$ & & \\
Eksklusi & $\mathrm{X}$ & $\mathrm{X}$ & & & \\
Pengalihan & $\mathrm{X}$ & & & & \\
\hline
\end{tabular}

Sumber: Ostrom dan Schlager (1999) seperti yang dikutip Satria (2009)

Perubahan kepemilikan dan penguasaan sumber daya air, berpengaruh terhadap perubahan konfigurasi akses terhadap sumber daya air tersebut. Kumpulan hak yang dimiliki oleh pemilik sebelumnya akan berkurang dengan diberikannya hak kepemilikan kepada pihak lain. Di sisi lain pengelolaan sumber daya air oleh swasta untuk kepentingan komersial tetap akan membawa kerusakan dan kelangkaan sumber daya air karena keinginan swasta untuk memperoleh keuntungan dari sumber daya (Fitri 2014).

\section{Teori Akses}

Ribot dan Peluso (2003) membedakan teori akses dan teori properti. Akses lebih kepada kemampuan sedangkan kepemilikan ada pada properti. Teori akses memperluas cakupan teori hak kepemilikan. Teori akses lebih menekankan tentang tata cara setiap orang mendapatkan manfaat dari sumber daya dibandingkan dengan semata-mata kepemilikan hak yang mengatur tentang hak dan tanggung jawab. Teori akses juga menganggap bahwa teori kepemilikan hanyalah salah satu cara atau mekanisme dalam mendapatkan akses terhadap sumber daya. Pengertian akses lebih mengutamakan pada kemampuan mendapatkan manfaat dibandingkan pada suatu kepemilikan yang ada. Akses seperti halnya properti selalu berubah, tergantung pada posisi individu dan kelompok serta kekuasaan dengan variasi hubungan sosial.

Ribot dan Peluso melihat bahwa ada semacam susunan jaringan akses. Akses membentuk bundles (kumpulan) dan webs (jaringan) kekuasaan yang memungkinkan orang atau institusi mendapatkan manfaat dari sumber daya air dan memungkinkan hilangnya hak masyarakat dari sumber daya yang dimilikinya. Akses pada bundle of power yang memberikan perhatian pada wilayah jaringan yang lebih luas pada hubungan sosial yang mendesak dan memungkinkan seseorang untuk mendapatkan keuntungan dari sumber daya tanpa memfokuskan diri pada hubungan kepemilikan semata.

Akses lebih melihat pada masalah-masalah mengenai siapa yang memanfaatkan (dan siapa yang tidak memanfaatkan) suatu sumber daya, apa cara yang digunakan untuk memanfaatkan sumber daya, kapan dan dalam keadaan seperti apa. Analisis akses membantu memahami mengapa beberapa orang atau institusi dapat memetik manfaat dari sumber daya, terlepas apakah mereka mempunyai hak atas sumber daya tersebut atau tidak. Dari uraian tersebut dapat disimpulkan bahwa analisis akses adalah proses mengidentifikasi dan memetakan mekanisme akses melalui penelaahan atas bagaimana akses diperoleh, dipelihara, dan dikendalikan.

\section{Konsep Sosial Ekonomi}

Pengertian sosial ekonomi sering dibahas secara terpisah. Pengertian sosial dalam ilmu sosial menunjuk pada objeknya yaitu masyarakat. Sementara ekonomi menunjuk pada keterkaitan objeknya yaitu rumahtangga. Soekanto (2006) mengatakan bahwa interaksi sosial adalah hubungan-hubungan sosial yang dinamis yang menyangkut hubungan seseorang, antar kelompok, maupun antara orang perorangan dengan kelompok manusia. Hubungan tersebut membentuk proses sosial yang merupakan aspek dinamis dalam kehidupan sosial yang terjadi dalam kehidupan manusia secara terus menerus. Proses sosial yang dapat mendekatkan atau yang mempersatukan diantaranya yaitu kerjasama. Menurut Jhonson dan Jhonson (2012) salah satu teori yang melandasi riset mengenai kerjasama, yaitu saling ketergantungan sosial. Saling ketergantungan sosial merupakan tindakan seseorang yang tidak dipengaruhi oleh tindakan lainnya. 
Kamus Besar Bahasa Indonesia (KBBI) mengartikan ekonomi berarti ilmu yang mengenai asas-asas produksi, distribusi dan pemakaian barang-barang serta kekayaan. Maka secara garis besar ekonomi diartikan sebagai aturan rumah tangga atau manajemen rumah tangga. Kondisi ekonomi dapat dilihat berdasarkan taraf hidup seseorang. Menurut BPS (2007) taraf hidup merupakan tingkat kemampuan seseorang untuk memenuhi kebutuhan hidupnya. Taraf hidup dapat diukur dengan melihat pendapatan, status rumah, jenis lantai, jenis dinding, bahan bakar memasak, fasilitas MCK, sumber penerangan rumahtangga, sumber air minum, pengeluaran konsumsi per bulan, dan aset kepemilikan. Menurut Soekanto (2006), sosial ekonomi adalah posisi seseorang dalam masyarakat berkaitan dengan orang lain dalam arti lingkungan pergaulan, prestasinya, dan hak-hak serta kewajibannya dalam hubungannya dengan sumber daya. Soekanto juga menyebutkan bahwa terdapat beberapa faktor-faktor yang mempengaruhi status sosial ekonomi masyarakat diantaranya, yaitu: (1) pekerjaan, (2) pendidikan, (3) pendapatan, (4) jumlah tanggungan orang tua, (5) kepemilikan barang berharga, (6) tempat tinggal, dan (7) partisipasi (hubungan) dalam masyarakat.

\section{Kerangka Pemikiran}

Sumber daya air sebagai kebutuhan dasar manusia merupakan hak bagi setiap orang untuk memanfaatkannya secara bebas.

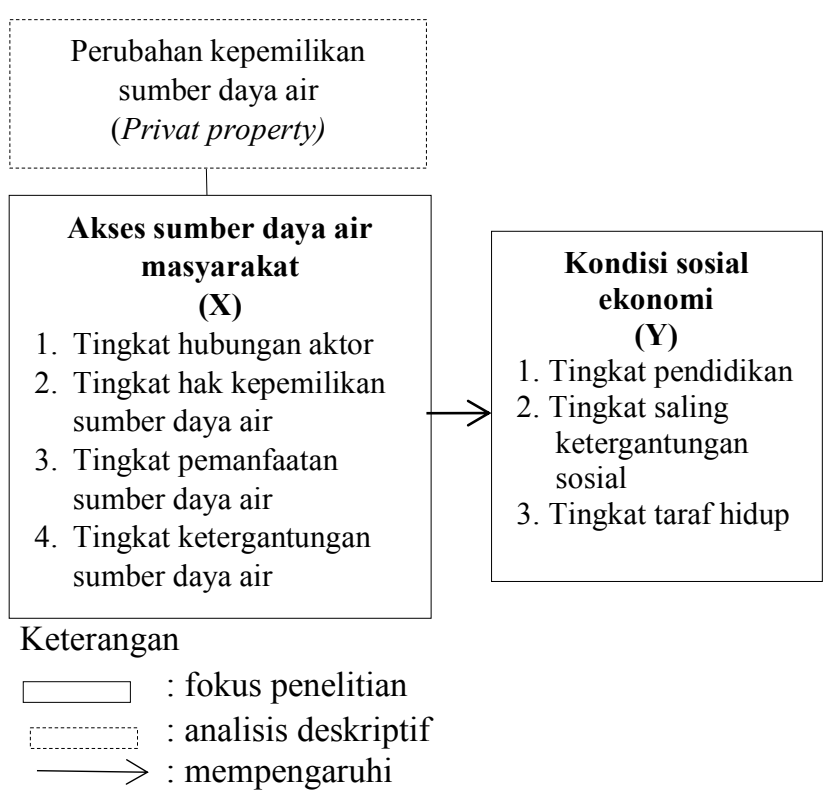

Gambar 1 Kerangka pemikiran
Keberadaan perusahan air minum sebagai privat property yang turut memanfaatkan sumber daya air tanah untuk kebutuhannya, memberikan dampak bagi perubahan akses dan pemanfaatan sumber daya air untuk pemenuhan kebutuhan domestik sosial ekonomi oleh masyarakat. Kerangka pemikiran penelitian ini mengacu pada analisis akses dan pemanfaatan sumber daya air oleh masyarakat terhadap kondisi sosial ekonomi yang dihadapi.

\section{METODE PENELITIAN}

Jenis penelitian yang digunakan pada penelitian ini adalah eksplanatori dengan pendekatan kuantitiatif yang didukung data kualitatif. Penelitian eksplanatori bertujuan untuk menguji suatu teori atau hipotesis untuk memperkuat atau bahkan menolak suatu hipotesis penelitian, serta menjelaskan hubungan kausal antara variabelvariabel yang mempengaruhi hipotesis.

Pendekatan kuantitatif dilakukan dengan metode survei, yaitu penelitian yang mengambil sebagian unit analisis dari populasi dengan menggunakan kuesioner sebagai alat pengumpul data primer. Metode survei akan dilakukan dengan memberikan panduan pertanyaan berupa kuesioner.

Pengambilan data kualitatif diperlukan untuk mengambil data yang bersifat deskriptif. Data kualitatif didapatkan dengan melakukan observasi lapang, wawancara mendalam kepada informan dengan menggunakan panduan pertanyaan, dan studi literatur. Informasi data kualitatif ini digunakan untuk mendukung dan sebagai interpretasi data hasil kuantitatif yang didapatkan. Data kualitatif juga digunakan untuk memberikan pemahaman mendalam mengenai suatu peristiwa dan gejala sosial, serta menggali berbagai realitas dan proses sosial secara deskriptif dan naratif.

Penelitian ini dilakukan di RT 03 dan RT 04, RW 03 Desa Sukamantri, Kecamatan Tamansari, Kabupaten Bogor, Jawa Barat. Pemilihan lokasi penelitian dilakukan secara sengaja (purposive). Alasan pemilihan lokasi penelitian ini adalah Desa Sukamantri memiliki sumber mata air dan menjadi salah satu tempat berdirinya Perusahaan AMDK. Berdirinya Perusahaan AMDK dan perumahan di wilayah RW 03 membuat kuantitas air menurun, serta akses pemanfaatan sumber daya air oleh masyarakat menjadi terbatas. Kegiatan penelitian dilaksanakan selama lima bulan dari September 2017 hingga Januari 2018. 
Populasi dalam penelitian ini adalah seluruh masyarakat pemanfaat sumber daya air sekitar wilayah Perusahaan AMDK dan Perumahan di RW 03 Desa Sukamantri. Unit analisis dalam penelitian ini adalah rumahtangga yang memanfaatkan sumber daya air untuk kebutuhan domestik di RT 03 dan RT 04 di RW 03 Desa Sukamantri. Pemilihan responden dalam penelitian menggunakan simple random sampling. Teknik ini dipilih karena responden yang menjadi sasaran bersifat homogen yaitu rumahtangga yang memanfaatkan sumber daya air untuk minum dan kebutuhan domestik. Jumlah responden pada penelitian sebanyak 35 rumahtangga yang akan dipilih dan diambil dari kerangka sampel (sampling frame). Wilayah RT 03 yang terdiri dari $28 \mathrm{KK}$ akan dipilih 15 responden, sedangkan pada wilayah RT 04 yang terdiri dari 45 $\mathrm{KK}$ akan dipilih 20 responden sehingga berjumlah 35 responden.

Jumlah informan dalam penelitian ini tidak dibatasi dan dilakukan secara sengaja (purposive) melalui teknik bola salju (snowballl sampling) yang memungkinkan perolehan informasi berkesinambungan antara informan yang satu dengan informan yang lainnya. Informan kunci dalam penelitian ini adalah pemerintah desa, karyawan pihak swasta, tokoh masyarakat, serta responden yang dinaikan statusnya menjadi informan. Pencarian informan ini akan berhenti saat tambahan informan tidak lagi menghasilkan pengetahuan baru atau berada di titik jenuh.

Data yang digunakan dalam penelitian ini terdiri dari data primer dan data sekunder. Data primer didapatkan langsung dilapang melalui survei dengan instrumen kuesioner kepada responden, observasi langsung, dan wawancara mendalam dengan pertanyaan terstruktur kepada informan yang telah ditentukan sebelumnya. Observasi dilakukan untuk mengumpulkan data berupa perilaku, kegiatan dan perbuatan yang dilakukan masyarakat secara objektif, memperoleh gambaran kondisi secara langsung, serta untuk kebutuhan dokumentasi.

Data sekunder merupakan data yang dikumpulkan dan sudah terlebih dahulu diolah oleh pihak lain. Data sekunder ini diperoleh melalui kajian pustaka dan analisis berbagai literatur yang terkait dengan sumber daya air, akses terhadap sumber daya, dan sosial ekonomi masyarakat. Data sekunder diperoleh dari kantor desa, Badan Pusat Statistik (BPS), dan sumber-sumber lainnya seperti internet, buku, jurnal penelitian, skripsi, tesis, dan literatur lainnya yang berkaitan dengan penelitian ini. Kegunaan data primer dan data sekunder ini untuk saling mendukung satu sama lain dan menyempurnakan hasil penelitian.

Teknik pengolahan data kuantitatif dan kualitatif dilakukan melalui reduksi data yakni pemilahan, pemusatan perhatian, serta penyederhanaan terhadap data sehingga dapat digunakan untuk menjawab tujuan penelitian. Analisis data yang digunakan dalam penelitian ini adalah analisis deskriptif. Analisis deskriptif sebagai analisis pendahuluan yang dibutuhkan untuk mengetahui karakteristik setiap variabel pada sampel penelitian.

Data kuantitatif diolah menggunakan uji statistik berupa uji regresi untuk mengetahui pengaruh akses sumber daya air terhadap kondisi sosial ekonomi masyarakat yang dilakukan oleh rumahtangga sekitar Perusahaan AMDK. Analisis data kualitatif dilakukan melalui tiga tahap yaitu reduksi data, penyajian data, dan verifikasi data hasil wawancara mendalam.

Data kuantitatif dan data kualitatif digabungkan dan diolah yang kemudian dianalisis untuk disajikan dalam bentuk teks naratif, matriks, bagan, dan gambar untuk memperoleh kesimpulan yang berkaitan dengan rumusan masalah dan tujuan penelitian. Selanjutnya melakukan verifikasi untuk menarik kesimpulan dari hasil yang telah diolah pada tahap reduksi. Penyimpulan hasil penelitian dilakukan dengan mengambil hasil analisis antar variabel yang konsisten.

\section{HASIL DAN PEMBAHASAN}

\section{Proses Perubahan Rezim Kepemilikan Sumber Daya Air}

Wilayah RT 03, RW 03 Desa Sukamantri pada awalnya terdapat sebuah taman yang memiliki sumber air dari mata air Gunung Halimun Salak. Taman sekarang telah dikuasai oleh perusahaan AMDK. Penguasaan sumber daya air oleh perusahaan terjadi melalui proses jual beli antara pihak pemilik taman dengan pihak perusahaan yang dilakukan dengan cara membeli lahan yang didalamnya terdapat mata air tersebut. Perusahaan air didirikan oleh SRT dan KYT pada tahun 2009. Saat awal berdiri, perusahaan air hanya memproduksi air baku, seiring berjalannya waktu pada tahun 2010 perusahaan air berkembang untuk memproduksi air minum dalam kemasan yang kemudian berubah menjadi perusahaan air minum 
dalam kemasan (AMDK).

Penjelasan mengenai perbandingan kekuasaan dan hak kepemilikasn sumber daya air sebelum dan sesudah hadirnya Perusahaan AMDK dijelaskan pada Tabel 4.

Tabel 4 Perbandingan kekuasaan dan hak kepemilikan sumber daya air sebelum dan sesudah berdirinya Perusahaan AMDK

\begin{tabular}{|c|c|c|}
\hline \multirow{2}{*}{$\begin{array}{l}\text { Indikator } \\
\text { perubahan }\end{array}$} & \multicolumn{2}{|c|}{ Perbandingan perubahan } \\
\hline & $\begin{array}{l}\text { Sebelum masuknya } \\
\text { perusahaan AMDK }\end{array}$ & $\begin{array}{l}\text { Sesudah masuknya } \\
\text { perusahaan AMDK }\end{array}$ \\
\hline $\begin{array}{l}\text { Sumber } \\
\text { mata air }\end{array}$ & $\begin{array}{l}\text { Sebagai fasilitas } \\
\text { umum untuk } \\
\text { kesejahteraan } \\
\text { - Sifat barang } \\
\text { sumber daya } \\
\text { common good } \\
\end{array}$ & $\begin{array}{l}\text { Sebagai sumber } \\
\text { komoditas } \\
\text { perusahaan } \\
\text { Sifat barang } \\
\text { sumber daya } \\
\text { privat good }\end{array}$ \\
\hline $\begin{array}{l}\text { Hak } \\
\text { kepemilikan } \\
\text { mata air }\end{array}$ & $\begin{array}{l}\text { - Communal } \\
\text { property regime } \\
\text { - Dikelola oleh } \\
\text { masyarakat } \\
\text { dengan sumber } \\
\text { dana pribadi } \\
\text { pemiliknya } \\
\text { - Bertujuan untuk } \\
\text { kesejahteraan } \\
\text { umum } \\
\text { - Masyarkat bebas } \\
\text { mengakses dan } \\
\text { memanfaatkan } \\
\end{array}$ & 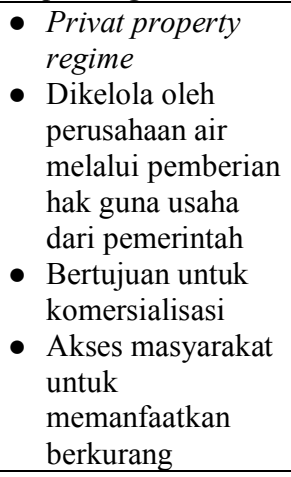 \\
\hline $\begin{array}{l}\text { Penguasaan } \\
\text { lahan }\end{array}$ & $\begin{array}{l}\text { - Masih terdapat } \\
\text { lahan sawah } \\
\text { - Terdapat } \\
\text { masyarakat yang } \\
\text { bekerja sebagai } \\
\text { petani } \\
\text { - KK RT 03 } \\
\text { berjumlah } 54 \mathrm{KK} \\
\text { - KK RT 04 } \\
\text { berjumlah } 68 \mathrm{KK}\end{array}$ & $\begin{array}{l}\text { - Lahan sawah dan } \\
\text { sebagian } \\
\text { pemukiman } \\
\text { terkonversi } \\
\text { - Sebagian } \\
\text { masyarakat beralih } \\
\text { mata pencaharian } \\
\text { dan kehilangan } \\
\text { tempat tinggal } \\
\text { - KK RT 03 } \\
\text { berjumlah } 28 \mathrm{KK} \\
\text { - KK RT 04 } \\
\text { berjumlah } 45 \mathrm{KK}\end{array}$ \\
\hline
\end{tabular}

Sumber: Data primer 2017

Sebelum masuknya perusahaan, masyarakat bebas mengakses (open access) dan menggunakan air taman untuk memenuhi kebutuhan domestik rumahtangga. Perpindahan kepemilikan lahan sekitar taman kepada perusahaan mengakibatkan terjadinya perubahan pengelolaan sumber daya air yang semula dikelola bersama masyarakat (common property regime) menjadi dikelola oleh badan usaha swasta (privat property regime). Sifat barang sumber daya air yang semula common good berubah menjadi private good yang apabila dikonsumsi oleh pihak lain akan mengurangi potensi konsumsi pihak lainnya. Perpindahan hak kepemilikan taman, menjadikan perusahaan sebagai proprietor memiliki hak pengelolaan (management right) dan hak pelarangan (exclusion right). Hakhak perusahaan untuk mengelola sumber daya air diberikan oleh negara. Negara sebagai pemilik (owner) sumber daya air memberikan izin pengusahaan air dan hak guna usaha atas air (rightbased access) kepada perusahaan.

Akses sumber daya air oleh perusahaan tidak hanya terbentuk oleh mekanisme akses berbasis hak, namun juga terkait dengan mekanisme struktural dan relasional. Akses hak perusahaan didukung oleh hubungan yang dibangun antar stakeholder yaitu pihak perusahaan dengan pemerintahan desa dan pemilik taman. Proses masuknya perusahaan diawali dengan pertemuan stakeholder terkait dengan melalui musyawarah dan mencapai beberapa kesepakatan bersama.

Peningkatan kebutuhan pasar akan air minum kemasan membuat pihak perusahaan harus memperluas wilayahnya. Permintaan lahan yang semakin banyak oleh pihak perusahaan menyebabkan sebagian masyarakat RT 03 harus pindah. Selain itu, pembangunan perumahan elite disamping perusahaan AMDK membuat kawasan RT 04 juga terkena dampak penyempitan lahan. Pembangunan perumahan tersebut membuat kuantitas air tanah semakin berkurang karena terserap oleh sumur-sumur pada perumahan elite. Hal ini berbeda dengan sumber air yang diperoleh oleh perusahaan AMDK yaitu mata air.

\section{Akses Sumber Daya Air oleh Masyarakat}

Setelah sumber mata air dijual ke perusahaan AMDK pada tahun 2009, masyarakat mulai membangun sumur pada setiap rumah yang bersumber dari air tanah. Saat musim kemarau tiba,sumur warga terkadang mengalami penurunan kuantitas air. Air tanah yang keluar hanya berjumlah sedikit, hal ini disebabkan oleh pembangunan kawasan perumahan elite di sekitar lingkungan warga RT 04, RW 03 Desa Sukamantri yang menggunakan sumur disetiap rumahnya. Jika terjadi kemarau, banyak warga yang mengunjungi perusahaan AMDK untuk meminta air terutama untuk kebutuhan minum dan memasak. Akses masyarakat dalam memanfaatkan sumber daya air dilihat dari empat indikator yang dijelaskan pada Tabel 5. 
Tabel 5 Frekuensi tingkat akses sumber daya air oleh masyarakat

\begin{tabular}{llrr}
\hline \multicolumn{1}{c}{ Indikator } & Kategori & Frekuensi & $\begin{array}{c}\text { Persentase } \\
(\%)\end{array}$ \\
\hline Tingkat hubungan aktor & Rendah & 21 & 60.00 \\
& Tinggi & 14 & 40.00 \\
& Total & 35 & 100.00 \\
\hline Tingkat hak & Rendah & 35 & 100.00 \\
kepemilikan sumber & Total & 35 & 100.00 \\
daya air & & & \\
\hline Tingkat pemanfaatan & Rendah & 23 & 65.70 \\
sumber daya air & Tinggi & 12 & 34.30 \\
& Total & 35 & 100.00 \\
\hline Tingkat ketergantungan & Rendah & 17 & 48.60 \\
terhadap sumber daya & Tinggi & 18 & 51.40 \\
air & Total & 35 & 100.00 \\
\hline Sumber Data primer 2017 & &
\end{tabular}

Sumber: Data primer 2017

Perusahaan AMDK memiliki hak kepemilikan yang bersifat temporal sehingga setiap tahun harus memperpanjang izin yang diberikan oleh negara. Setiap masa perpanjangan izin, perusahaan AMDK mengadakan musyawarah dengan tokoh masyarakat, yaitu ketua RT 03 dan RT 04. Tokoh masyarakat berperan sebagai perantara antara hubungan perusahaan dengan masyarakat. Sebelum berdiskusi dengan perusahaan, tokoh masyarakat menampung aspirasi warga terlebih dahulu yang kemudian disampaikan dalam musyawarah. Hal yang didisuksikan yaitu mengenai kerja sama antara pihak swasta dengan masyarakat, serta apa kebutuhan dan harapan dari masyarakat. Musyawarah antara perusahaan AMDK dengan tokoh masyarakat hanya dilakukan setiap setahun sekali, dan tidak pernah melibatkan masyarakat secara langsung. Hal tersebut menyebabkan tingkat hubungan aktor termasuk dalam kategori rendah sebesar 60 persen.

Pada awal Juni 2017 perusahaan membuat fasilitas umum keran mata air diluar perusahaan untuk masyarakat, sehingga mereka tidak harus keluarmasuk perusahaan lagi untuk meminta air. Ketika musim kemarau, fasilitas keran dapat memenuhi kebuhan air karena kuantitasnya yang selalu berlimpah. Sehingga sebelum dan sesudah hadirnya perusahaan AMDK, kebutuhan atas air tetap masih dapat terpenuhi.

Tingkat hak dan kepemilikan dan tingkat pemanfaatan sumber daya air oleh masyarakat termasuk dalam kategori rendah, secara berurutan sebesar 100 persen dan 65,7 persen. Perpindahan kepemilikan dan penguasaan mata air membuat masyarakat sebagai authorized user hanya memiliki hak untuk mengakses (access right) dan memanfaatkan (withdrawal right) sumber mata air saja. Hal ini membuat kesempatan masyarakat untuk memanfaatkan mata air menjadi berkurang, dan terbatas.

Sementara tingkat ketergantungan sumber daya air oleh masyarkat termasuk dalam kategori tinggi sebesar 51,4 persen. Hal tersebut disebabkan oleh jumlah kebutuhan air rumahtangga yang dimanfaatkan setiap hari dipengaruhi oleh jumlah anggota keluarganya. Kebutuhan sumber daya air yang tinggi untuk memenuhi kebutuhan domestik membuat masyarakat sangat bergantung dengan sumber daya air.

\section{Kondisi Sosial Ekonomi Masyarakat Setelah terjadi Masuknya Perusahaan AMDK}

Sosial ekonomi dalam penelitian menunjuk pada objeknya yaitu rumahtangga. Kondisi sosial ekonomi pada rumahtangga responden penelitian dilihat dari tiga indikator yang dapat dilihat pada Tabel 6 .

Tabel 6 Frekuensi tingkat kondisi sosial ekonomi masyarakat

\begin{tabular}{llrr}
\hline \multicolumn{1}{c}{ Indikator } & Kategori & Frekuensi & $\begin{array}{r}\text { Persentase } \\
(\%)\end{array}$ \\
\hline Tingkat pendidikan & Rendah & 24 & 68.60 \\
& Tinggi & 11 & 31.40 \\
& Total & 35 & 100.00 \\
\hline Tingkat taraf hidup & Rendah & 23 & 65.70 \\
& Tinggi & 12 & 34.30 \\
& Total & 35 & 100.00 \\
\hline Tingkat saling & Rendah & 17 & 48.60 \\
ketergantungan sosial & Tinggi & 18 & 51.40 \\
& Total & 35 & 100.00 \\
\hline
\end{tabular}

Sumber: Data primer 2017

Pengusahaan lahan oleh perusahaan AMDK dan orang luar desa menyebabkan sebagian masyarakat kehilangan mata pencahariannya. Idealnya ketika terdapat banyak industri di desa maka masyarakat di desa tersebut mendapatkan peluang yang lebih besar untuk mengakses pekerjaan-pekerjaan yang tersedia di perusahaan. Awal kehadiran perusahaan di desa sebagian masyarakat berharap akan mendapatkan pekerjaan yang lebih baik, namun pada perjalannya tidak mudah bekerja di Perusahaan AMDK karena terdapat beberapa syarat sebagai kualifikasi yang harus dipenuhi, salah 
satunya yaitu syarat pendidikan minimal SMA.

Tingkat pendidikan kepala rumahtangga termasuk dalam kategori rendah yaitu 68,6 persen. Pendidikan rendah tersebut berkaitan dengan rendahnya penghasilan yang menyebabkan rendahnya biaya pendidikan sehingga tidak bisa melanjutkan ke jenjang pendidikan selanjutnya.

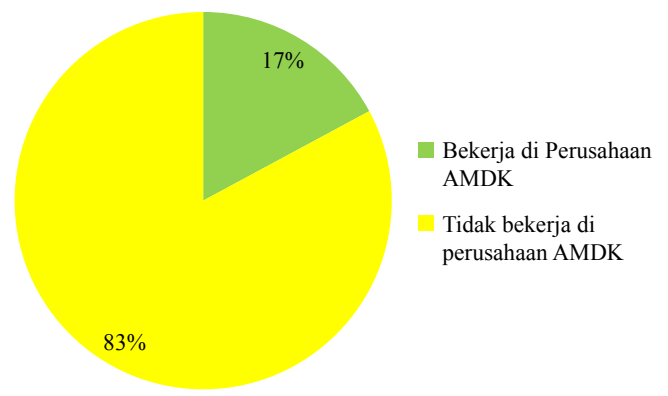

Gambar 2 Responden yang bekerja di Perusahaan AMDK

Pada Gambar 2 menjelaskan bahwa jumlah responden yang bekerja di perusahaan AMDK sebesar 17 persen lebih sedikit dibandingkan dengan jumlah responden yang bekerja di luar perusahaan AMDK sebesar 83 persen. Hal ini disebabkan karena tingkat pendidikan responden lulusan SMA berjumlah lebih sedikit dibandingkan dengan yang lulusan SD. Selain itu, terdapat responden yang memilih untuk tidak bekerja di perusahaan AMDK meskipun memiliki pendidikan akhir SMA.

Tingkat taraf hidup rumahtangga termasuk pada kategori rendah sebesar 65,7 persen. Taraf hidup dilihat dari pendapatan dan pengeluaran rumahtangga setiap bulan, fasilitas rumah, dan aset kepemilikan.

Tabel 7 Frekuensi pendapatan rumahtangga tiap bulan

\begin{tabular}{crr}
\hline Pendapatan/bulan & Jumlah & Persentase (\%) \\
\hline Rp 450 000 - Rp 835 000 & 6 & 17.10 \\
Rp 836 000 - Rp 2 265000 & 21 & 60.00 \\
Rp 2 266 000 - RP 3 000 000 & 8 & 22.90 \\
Total & 35 & 100.00 \\
\hline
\end{tabular}

Sumber: Data primer 2017

Pendapatan rumahtangga setiap bulan berkisar antara Rp 450.000 hingga Rp 3.000.000. Sebagian besar 31,43 persen rumahtangga memperoleh pendapatan sebesar Rp 835.000 hingga $\mathrm{Rp}$ 2.265.000 setiap bulan.
Tabel 8 Frekuensi pengeluaran rumahtangga tiap bulan

\begin{tabular}{crr}
\hline Pengeluaran/bulan & Jumlah & Persentase (\%) \\
\hline Rp 501 000 - Rp 1 029 000 & 18 & 51.40 \\
Rp 1 030 000 - Rp 1 113000 & 6 & 17.10 \\
Rp 1 114000 - RP 2 396000 & 11 & 31.60 \\
Total & 35 & 100.00 \\
\hline
\end{tabular}

Sumber: Data primer 2017

Sementara pengeluaran rumahtangga tiap bulan berkisar Rp 501.000 hingga Rp 2.396.000. Sebagian besar 51,4 persen rumahtangga mengeluarkan pengeluaran sebesar Rp 501.000 hingga $\mathrm{Rp} 1.029 .000$ setiap bulan.

Setelah berdirinya perusahaan AMDK, sumber air minum yang dikonsumsi masyarakat menjadi beragam yaitu air tanah (sumur), mata air (fasilitas keran perusahaan AMDK), dan air kemasan isi ulang.

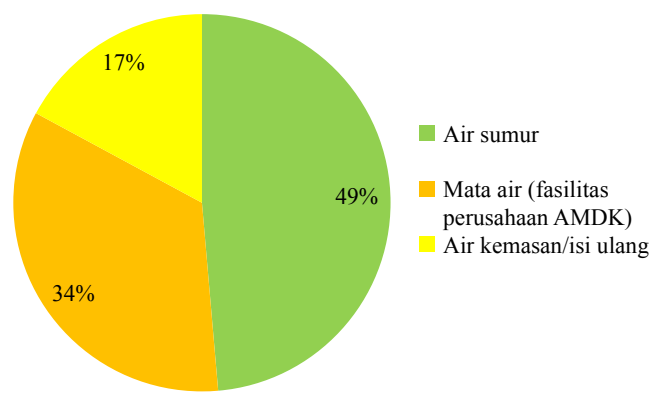

Gambar 2 Sumber air minum

Sebagian besar rumahtangga sebesar 49 persen menggunakan air sumur karena mudah didapatkan. Mata air digunakan karena 34 persen rumahtangga percaya bahwa air tersebut bersih dan aman langsung di konsumsi. Sementara hanya 17 rumahtangga menggunakan air kemasan, karena air sumur yang digunakan terdapat endapan tanah, dan berlokasi tidak dekat dengan perusahaan AMDK.

Penurunan kuantitas air saat musim kemarau membuat masyarakat memiliki ketergantungan sosial untuk saling tolong-menolong membantu tetangga jika mengalami kekeringan atau kesulitan air, kerja bakti membersihkan lingkungan,dan mengingatkan untuk saling menjaga lingkungan dan hemat air. Tingkat ketergantungan sosial rumahtangga termasuk pada kategori tinggi sebesar 51,4 persen. Pada acara kegiatan sosial di Desa, pihak perusahaan seringkali membantu pelaksanaan kegiatan dengan persyaratan yang sudah ditentukan, yaitu masyarakat harus membuat sebuah proposal kegiatan sosial terlebih dahulu. Kegiatan sosial yang biasanya diberikan air minum gratis yaitu 
seperti kegiatan pengajian, acara besar keagamaan, tujuh belasan, dan kerja bakti.

\section{Pengaruh Akses Pemanfaatan Sumber Daya Air terhadap Kondisi Sosial Ekonomi}

Menurut Sasongko (2010) air sangat berhubungan dengan hak hidup sesesorang sehingga air tidak bisa dilepaskan dalam kerangka hak asasi manusia. Air sebagai sumber daya dapat memberikan manfaat bagi masyarakat meliputi penggunaan air untuk kebutuhan rumahtangga, dan aktivitas masyarakat lainnya. Sifat air seperti itu tidaklah menyalahi kodrat, karena sumber daya air dimanfaatkan guna memenuhi kebutuhan hidup manusia, baik kebutuhan sosial maupun ekonomi. Berikut adalah Tabel frekuensi tingkat akses pemanfaatan sumber daya air dan tingkat sosial ekonomi masyarakat.

Tabel 9 Frekuensi akses pemanfaatan sumber daya air dan sosial ekonomi masyarakat

\begin{tabular}{llrr}
\hline \multicolumn{1}{c}{ Indikator } & Kategori & Frekuensi & $\begin{array}{c}\text { Persentase } \\
(\%)\end{array}$ \\
\hline Tingkat akses & Rendah & 21 & 60.00 \\
pemanfaatan sumber & Tinggi & 14 & 40.00 \\
daya air & Total & 35 & 100.00 \\
\hline Tingkat sosial ekonomi & Rendah & 22 & 62.80 \\
& Tinggi & 13 & 37.20 \\
& Total & 35 & 100.00 \\
\hline
\end{tabular}

Sumber: Data primer 2017

Masyarakat RT 03 dan RT 04 memilik tingkat akses pemanfaatan sumber daya air, dan kondisi sosial ekonomi pada kategori rendah dengan persentase secara berurutan yaitu 60 persen dan 62,8 persen.

Pengaruh antara variabel akses pemanfaatan sumber daya air terhadap kondisi sosial ekonomi ditentukan oleh hasil uji $t$, dimana nilai $t_{\text {hitung }}$ harus lebih besar dari pada nilai tabel 33 yaitu 1.692. Sementara untuk mengetahui kuatnya pengaruh antar variabel ditentukan oleh nilai sig yang harus lebih kecil dari 0.05 .

Tabel 10Pengaruh indikator akses sumber daya air terhadap tingkat sosial ekonomi masyarakat

\begin{tabular}{lrrr}
\hline \multicolumn{1}{c}{ Indikator } & \multicolumn{1}{c}{$\mathrm{B}$} & \multicolumn{1}{c}{$\mathrm{t}$} & Sig. \\
\hline (Constant) & 12.525 & & \\
Hubungan aktor & .124 & .623 & .538 \\
Hak kepemilikan sumber daya air & -1.383 & -.830 & .413 \\
Pemanfaatan sumber daya air & 1.544 & 3.078 & .004 \\
Ketergantungan sumber daya air & .907 & 5.219 & .000 \\
\hline
\end{tabular}

Sumber: Data primer 2017
Indikator-indikator variabel akses pemanfaatan sumber daya air diuji dengan uji regresi linear berganda untuk melihat besar pengaruh dari masing-masing indikator terhadap kondisi sosial ekonomi. Indikator tingkat hubungan aktor, dan tingkat hak kepemilikan sumber daya air memiliki nilai $t_{\text {hitung }}$ yang lebih kecil dari nilai $t_{\text {tabel, }}$ dan nilai sig yang lebih besar dari 0.05 . Hal ini menunjukkan bahwa hubungan aktor dan hak kepemilkan sumber daya air tidak berpengaruh signifikan terhadap kondisi sosial ekonomi rumahtangga, sehingga menolak hipotesis uji.

Sementara indikator pemanfaatan sumber daya air, dan tingkat ketergantungan sumber daya air oleh masyarakat memiliki nilai thitung yang lebih besar dari nilai $t_{\text {tabel}}$, dan nilai sig yang lebih kecil dari 0.05. Hal ini menunjukkan bahwa idniaktor pemanfaatan dan ketergantungan masyarakat terhadap sumber daya air berpengaruh signifikan terhadap kondisi sosial ekonomi rumahtangga, sehingga menerima hipotesis uji.

Pada Tabel 10 diketahui bahwa jika tidak ada hubungan aktor, hak dan kepemilikan sumber daya air, pemanfaatan sumber daya air, dan ketergantungan sumber daya air maka nilai konsisten dari kondisi sosial ekonomi yaitu sebesar 12.525. Indikator-indikator akses sumber daya air memiliki nilai koefisien regresi sebesar 0.124 untuk tingkat hubungan aktor, nilai -1.383 untuk tingkat hak dan kepemilikan sumber daya air, nilai 1.544 untuk pemanfaatan sumber daya air, dan nilai 0.907 untuk ketergantungan sumber daya air, sehingga dapat membentuk persamaan yaitu $\mathrm{Y}=12.525+$ $0.124 \mathrm{X}_{1}-1.383 \mathrm{X}_{2}+1.544 \mathrm{X}_{3}+0.907 \mathrm{X}_{4}$.

Koefisien regresi pada tiap indikator mempengaruhi pada besar jumlah perubahan yang terjadi pada kondisi sosial ekonomi yang disebabkan oleh perubahan nilai pada masing-masing indikator. Nilai koefisien regresi yang berbeda pada setiap indikator menunjukan bahwa masing-masing indikator memiliki besar pengaruh yang berbeda.

Selanjutnya untuk melihat pengaruh antara variabel akses pemanfaatan sumber daya air terhadap kondisi sosial ekonomi diuji dengan uji regresi linear sederhana.

Tabel 11Pengaruh akses pemanfaatan sumber daya air terhadap kondisi sosial ekonomi masyarakat

\begin{tabular}{lcccc}
\hline & Indikator & $\mathrm{B}$ & $\mathrm{t}$ & Sig. \\
\hline (Constant) & 16.587 & 2.866 & .007 \\
\hline
\end{tabular}




\begin{tabular}{cccc}
\hline Akses pemanfaatan sumber daya air & .453 & 4.076 & .000 \\
\hline$R$ square & .335 & &
\end{tabular}

Sumber: Data primer 2017

Hasil nilai $R$ square menjelaskan bahwa variabel akses pemanfaatan sumber daya air memiliki pengaruh sebesar 33,5 persen terhadap kondisi sosial ekonomi. Variabel akses pemanfaatan sumber daya air memiliki nilai thitung yang lebih besar dari nilai $t_{\text {tabel, }}$ dan nilai sig yang lebih kecil dari 0.05. Hal ini menunjukkan bahwa akses pemanfaatan sumber daya air memiliki pengaruh signifikan terhadap kondisi sosial ekonomi rumahtangga, sehingga menerima hipotesis uji.

\section{KESIMPULAN DAN SARAN}

\section{Simpulan}

Penguasaan sumber mata air di RW 03 Desa Sukamantri telah berubah dari communal property regime menjadi dikuasai oleh miliki swasta, yaitu perusahaan AMDK. Akses pemanfaatan sumber daya air oleh masyarakat termasuk dalam kategori rendah, karena masyarakat mengalami keterbatasan hak akses (access right) dan hak pemanfaatan (withdrawal right) terhadap sumber daya air. Hal tersebut disebabkan oleh pemberian izin kepada swasta untuk menguasai mata air yang menyebabkan berkurangnya akses masyarakat terhadap sumber mata air, dan menyebabkan alih fungsi lahan, sehingga sebagian masyarakat yang mula bekerja sebagai petani harus berubah mata pencaharian menjadi buruh pabrik, pedagang, buruh bangunan, buruh sepatu, dan lain-lain.

Kondisi sosial ekonomi sebagian besar masyarakat setelah terjadinya perubahan rezim kepemilikan termasuk pada kategori rendah. Hal tersebut disebabkan karena hanya sebagian kecil masyarakat desa yang merasa diuntungkan dengan kehadiran perusahaan AMDK. Hadirnya perusahaan memberi peluang sebuah pekerjaan untuk bekerja sebagai buruh pabrik yang dapat memberikan penghasilan lebih besar dibandingkan sebelum adanya perusahaan. Kehilangan pekerjaan karena hadirnya perusahaan AMDK tidak secara otomatis membuat mereka bisa bekerja di perusahaan. Perusahaan mensyaratkan berbagai kriteria untuk diterima bekerja di pabrik, salah satunya yaitu minimal berpendidikan SMA.

Masyarakat sudah cukup senang dengan bantuan fasilitas keran mata air diluar perusahaan, dan bantuan berupa air gelas kemasan gratis pada setiap kegiatan sosial di desa dengan syarat memberikan proposal kegiatan yang akan dilakukan. Masyarakat sekarang menggunakan air sumur sebagai sumber air untuk pemenuhan kebutuhan domestik seperti mencuci, mandi, dan memasak. Sedangkan untuk air minum, sebagian besar masyarakat sebesar 49 persen menggunakan air sumur, namun terdapat juga sebagian masyarakat yang memanfaatkan fasilitas keran mata air sebesar 34 persen, dan masyarakat yang membeli air kemasan isi ulang sebesar 17 persen.

Berdasarkan pada hasil uji regresi didapatkan kesimpulan bahwa indikator tingkat hubungan aktor, dan tingkat hak kepemilikan sumber daya air menolak hipotesis, sementara tingkat pemanfaatan dan tingkat ketergantunga sumber daya air menerima hipotesis. Akses pemanfaatan sumber daya air oleh masyarakat memiliki pengaruh kuat sebesar 33,5 persen terhadap kondisi sosial ekonomi. Hal ini menunjukan bahwa hipotesis diterima dengan pengaruh positif bahwa akses pemanfaatan sumber daya air oleh masyarakat mempengaruhi kondisi sosial ekonomi, yaitu akses pemanfaatan sumber daya air yang rendah mempengaruhi rendahnya kondisi sosial ekonomi rumahtangga yang dialami.

\section{Saran}

Peneliti memiliki saran yang merujuk pada kesimpulan untuk meningkatkan akses masyarakat terhadap sumber daya air. Saran yang dapat diajukan antara lain sebagai berikut:

1. Bagi pemerintah desa, diharapkan dapat meningkatkan perannya dalam upaya menangani permasalahan tersebut melalui pembuatan kebijakan tentang batas pengambilan sumber air bagi seluruh kalangan masyarakat, dan membatasi hadirnya privatisasi lahan di Desa Sukamantri.

2. Bagi pihak swasta perlu meningkatkan hubungan langsung dan peran modal sosial dengan masyarakat sehingga terjalin pola hubungan yang kuat, dan dapat saling memberikan keuntungan.

3. Bagi masyarakat diharapkan menggunakan air secara hemat, dan lebih peduli terhadap lingkungan sekitarnya.

4. Bagi akademisi, penelitian ini dapat memperlihatkan pengaruh akses pemanfaatan sumber daya air terhadap kondisi sosial ekonomi 
masyarakat di Desa Sukamantri. Penelitian ini juga dapat dijadikan pustaka untuk melakukan penelitian yang serupa.

5. Saran peneliti ini berarti bahwa kerjasama berbagai pihak diperlukan dalam mengupayakan kelestarian, keberlangsungan sumber daya air dan terpenuhinya akses sumber daya air yang lebih adil bagi semua pihak, terutama bagi masyarakat.

\section{DAFTAR PUSTAKA}

[BPS] Badan Pusat Statistik. 2007. Analogi Tipe Kemiskinan Perkotaan: Studi Kasus Jakarta Utara.

Bromley D.W. 1991. Property Rights Regimes In The RNP. Appendix E.

Fitri N. 2014. Kontestasi Aktor dan Kepentingan Terhadap Sumber Daya Air di Sukabumi [tesis]. Bogor (ID): Institut Pertanian Bogor.

Hardin G. 1968. The Tragedy of The Commons. Science, Vol. 162. pp. 1243-1248.

Jhonson DW, Jhonson FP. 2012. Dinamika Kelompok: Teori dan Keterampilan. Jakarta (ID): Permata Puri Media

Kodoatie R, Sjarie R. 2008. Pengelolaan Sumber Daya Air Terpadu. Yogyakarta (ID): ANDI.

Ostrom E, Schroeder, Wynne. 1993. Institutional incentives and sustainable development: Infrastructure policies in perspective. Boulder, CO: Westview Press.

Ostrom E. 2005. Understanding Institutional Diversity. Princeton and Oxford: Princenton University Press.

Rustiadi E, Saefulhakim S, Panuju D. 2011. Perencanaan pengembangan wilayah. Jakarta (ID): Cresrpent Press dan Yayasan Obor.

Ribot J.C. dan Peluso N.L. 2003. A Theory of Access. Journal Of Rural Sociology. 68 (2) Rural Sociological Society. Hlm 153-181

Sasongko A. 2010. Komersialisasi Sumber Daya Air. Perencanaan Pembangunan. 16(1). [Internet]. [Diunduh pada 23 Juni 2017]. Tersedia pada http://perpustakaan.bappenas.go.id/lontar/fil e? file=digital/95192-7Perencanaan\%20Pembangunan\%20edisi-1th-2010.pdf
Satria A. 2009. Pesisir dan Laut untuk Rakyat. Bogor (ID): IPB Press.

Shiva V. 2002. Water Wars: Privatisasi, Profit dan Polusi. Yogyakarta [ID]: Insist Press.

Singarimbun M. 2012. Metode Penelitian Survei. Effendi S, Tukiran, editor. Jakarta (ID): LP3ES.

Soekanto, Soerjono. 2006. Sosiologi Suatu Pengantar. Jakarta (ID): Raja Grafindo Persada.

[UU] Undang-undang Republik Indonesia Nomor 7 Tahun 2004 tentang Sumber Daya Air.

Wade R. 1987. The management of common property resources: Collective action as an alternative to privatisation or state regulation. Journal of Economics. 11(2): Cambridge University. [Internet]. [Diunduh pada 28 Agustus 2017]. Tersedia pada: https://academic.oup.com/cje/articleabstract/11/2/95/1679729? redirectedFrom $=\mathrm{f}$ $\underline{\text { ulltext }}$ 